УДК 544.77.032.1

\title{
MOLECULAR DYNAMICS SIMULATIONS OF SILVER NANOPARTICLES OF CUBIC AND BIPYRAMIDAL SHAPE
}

\section{M.M. Blazhynska, A.V. Kyrychenko, O.N. Kalugin}

\begin{abstract}
The crystalline structure, the perfect face-centered cubic (fcc) atom packing and macroscopic morphological stability of sharp-edged silver nanoparticles of cubic and bipyramidal shapes were compared against quasi-spherical nanoparticles by using classical molecular dynamics (MD) simulations. A series of silver nanocubes (AgNCs) and nanobipyramides (AgNBs) of different sizes varying from 44 up to 1156 atoms were considered. Our MD simulations revealed that starting from the preformed perfect crystalline structures the initial shape was preserved for cubic and bipyramidal nanoparticles composed of more than 256 atoms. Surprisingly, the rapid loss of the cubic-shape morphology and transformation into the non-fcc-structure were found for the smaller AgNCs composed of less than 172 atoms. No such loss of the preformed crystalline structure was noticed for bipyramidal and quasi-spherical nanoparticles. The analysis of the binding energy of the outermost Ag surface atoms suggests that the loss of the perfect cubic shape, rounding and smoothing of sharp edges and corners were driven by the tendency towards the increase in their coordination number.
\end{abstract}

Keywords: silver, nanoparticle, nanocube, nanobipyramide, fcc, sharp-edged, molecular dynamics simulation.

\section{Introduction}

Silver nanoparticles (AgNPs) have gained the growing attention due to their great performance in a broad range of applications, ranging from spectroscopic techniques based on surface-enhanced Raman scattering and metal-enhanced fluorescence up to numerous life-science applications, such as in vivo cellular imaging and sensing [1-3]. In recent years, particular attention has been paid to synthesis and characterization of sharp-edged AgNPs [4], because their optical, electronic and catalytic properties are strongly dependent on the number of constituent atoms and morphology [1,5-7]. The simple chemistry enables the tuning of these properties by varying the shape, ratio and number of the corners and edges that holds promise for their applications in many industrially and technologically important phenomena, ranging from chemical engineering to nano-science [8-11]. However, the complex interplay among the physico-chemical properties, such as size, morphology, charge, and ligand coating, often makes the interpretation of the experimental results difficult $[6,7]$.

Despite the substantial progress made in the chemical fabrication of sharp-edged silver nanostructures, there is less understanding of their morphological stability where high resolution methods are still difficult to apply [12]. Therefore, the atomic-scale information, which is not directly accessible by experimental studies, is often tested out by various types of computational chemistry methods. Among these methods, molecular dynamics (MD) simulation has become a powerful tool, which can effectively complement experiments to design well-defined nanostructures [6,13] and may facilitate the investigation of structure of metal nanoparticles at the atomic level [14]. MD simulation studies have already provided the important insight into solution-phase synthesis of silver nanostructures that involves the seeded growth $[15,16]$, aggregation of silver clusters, as well as adsorption of stabilizing agents and solvent molecules onto the exposed facets of inorganic metal nanocrystals $[17,18]$. Numerous MD simulation studies of isolated quasi-spherical metal nanoparticles, as well as nanoparticles protected by organic ligands [19-21] and polymers [22-26], have been conducted. However, the reliability of classical MD simulations of non-spherical nanoparticles with sharp edges and corners, such as cubes, pyramids, octahedrons, rods, etc., is still poorly understood $[15,27,28]$.

The main goal of our work was to benchmark a scope and limitations of classical MD simulations for studying of the structure of sharp-edged silver nanoparticles with cubic (AgNCs) and bipyramidal (AgNBs) shapes (Figure 1). A series of silver nanocubes and nanobipyramides of different sizes, varying from 44 up to 1156 atoms, were considered. The relative stability of silver nanoparticles of the different shapes was found to be correlated with the binding energy and the coordination numbers of the outermost low-coordinated Ag surface atoms. 


\section{Molecular dynamics simulation setup}

The initial configuration of the silver nanocubes (AgNCs) and nanobipyramides (AgNB) were approximated by the preformed perfect face-centered cubic $(f c c)$ crystalline structure (Fig. 1). All silver nanoparticles consisted of neutral, non-polarizable silver atoms with the zero charge. The repulsion and dispersion terms of the nonbonded interactions between silver atoms were computed by using the Lennard-Jones 12-6 potential energy function (Fig. 1, Eq. 1), which describes the dependence of the potential interaction energy $V_{\mathrm{LJ}}\left(r_{\mathrm{ij}}\right)$ of two silver atoms as a function of the interatomic distance. The nonbonded interaction parameters Ag-Ag $\sigma=0.264 \mathrm{~nm}$ and $\varepsilon=19.0587 \mathrm{~kJ} / \mathrm{mol}$ were taken from our recent works $[22,29]$. No any rigid bonds and restraints were applied between silver atoms, so that the silver core crystalline structure was maintained by the $\mathrm{Ag}-\mathrm{Ag}$ nonbonded $\mathrm{LJ}$ interactions.

Each Ag nanostructure was simulated in vacuum according to the following procedure: (1) Steepest descent energy minimization was performed for 500 steps. (2) Initial atomic velocities were generated with the Maxwellian distribution at $\mathrm{T}=250 \mathrm{~K}$. Then, productive MD sampling was carried out at the reference temperature of $\mathrm{T}=303 \mathrm{~K}$, which was kept constant using the Berendsen weak coupling scheme with the temperature coupling constant of $\tau_{T}=0.1 \mathrm{ps}$ [30]. To test the reproducibility of our MD simulations, 3-5 independent MD runs were carried out for each studied system, starting from different initial distributions of Maxwellian atomic velocities. The cutoff distance of $0.8 \mathrm{~nm}$ was used for Lennard-Jones interactions. The MD simulation time step was $2 \mathrm{fs}$ with the neighbor list updates every $10 \mathrm{fs}$. The MD simulations were carried out using the GROMACS set of programs, version 4.6.5 [31]. Molecular graphics and visualization were performed using VMD 1.9.2 [32].

a)

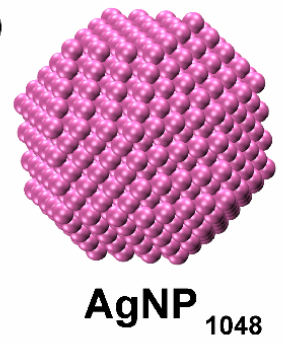

b)

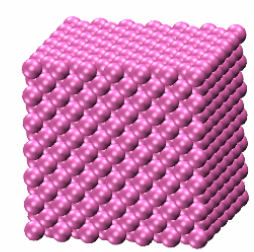

AgNC

c)

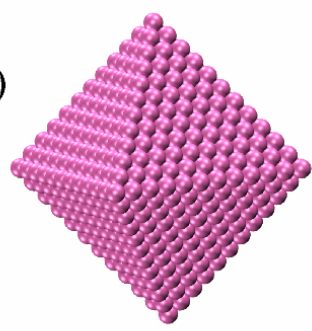

AgNB d)

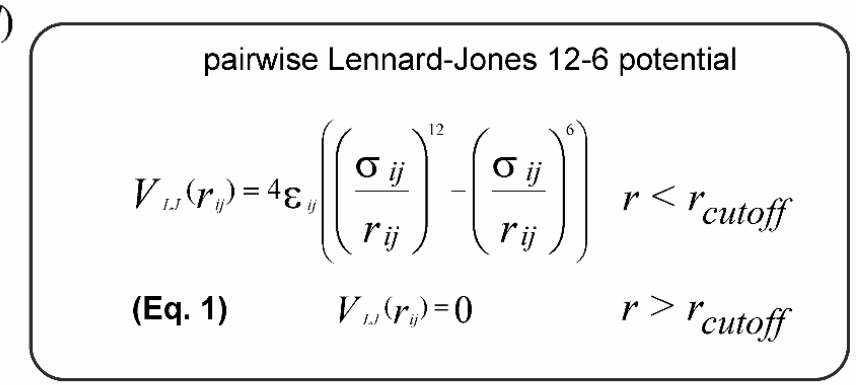

Lennard-Jones interatomic potential for Ag-Ag interaction

e)

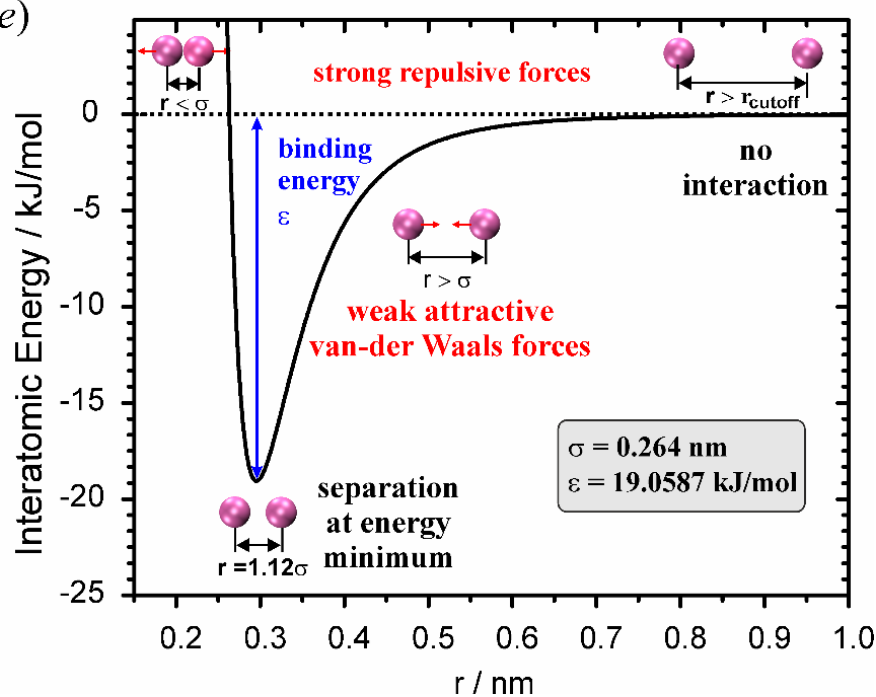

Figure 1. Silver nanostructures: $(a)$ - truncated polyhedron $\left(\mathrm{AgNP}_{1048}\right),(b)$ cube $\left(\mathrm{AgNC}_{1099}\right)$, (c) bipyramide $\left(\mathrm{AgNB}_{1156}\right) .(d-e)$ The Lennard-Jones (LJ) 12-6 potential energy function and the example of the LJ potential for Ag-Ag. 


\section{Results and Discussion}

MD Simulations of Morphological Stability. The morphological stability, crystalline structure and the perfect face-centered cubic $(f c c)$ atom packing were considered for series of preformed silver polyhedrons, nanocubes and bipyramides of varying sizes from $N=44$ up to 1156 atoms (Fig. 1). Our MD simulations revealed that the morphological stability of the preformed silver cubic-shape $f c c$-nanocrystals was size-dependent. MD simulations of each system AgNC was repeated from 3 to 5 times, starting from different initial distributions of Maxwellian atomic velocities. In the most cases, the perfect cubic shape and the $f c c$ crystalline structure were reproduced for AgNCs composed of $N=256-1099$ atoms. In some single MD runs, $f c c$ lattice defects due to displacement of a single $\mathrm{Ag}$ atom could be observed. However, for the smaller $\mathrm{AgNC}$ with $N=172$, all independent MD runs revealed the appearance of multiple crystalline lattice defects and the significant loss of the sharp corners and edges. Upon a further decrease in $N$ to 63-108, the complete loss of the cubic shape occurred (Fig. 2). In contrast, in all the cases of AgNBs and quasi-spherical AgNPs of different sizes with $N=38-1156$ MD simulations reproduced the initial morphology and the perfect $f c c$ crystalline structure.

Root Mean Square Displacements. To characterize the stability of Ag nanostructures, their structures were analyzed by calculating the root mean square displacement (RMSD) of $\mathrm{Ag}$ atoms as a function of time (Fig. 2). The RMSD of all Ag atoms was calculated with the respect to their positions in a perfect $f c c$ structure by using the GROMACS utility $g_{-} r m s$, which carries out least-square fitting the current $\mathrm{Ag}$ nanostructure $\left(\tau_{2}\right)$ to its initial perfect structure $\left(\tau_{1}=0\right)$ (Eq. 2).

$$
\begin{gathered}
\operatorname{RMSD}\left(\tau_{1}, \tau_{2}\right)=\left[\frac{1}{M} \sum_{i=1}^{N} m_{i} \cdot\left\|r_{i}\left(\tau_{1}\right)+r_{i}\left(\tau_{2}\right)\right\|^{2}\right]^{\frac{1}{2}} \\
M=\sum_{i=1}^{N} m_{i}
\end{gathered}
$$

where $M$ is given by (Eq. 3) and $r_{\mathrm{i}}(\tau)$ is the position of silver atom $i$ at time $\tau$ [33].

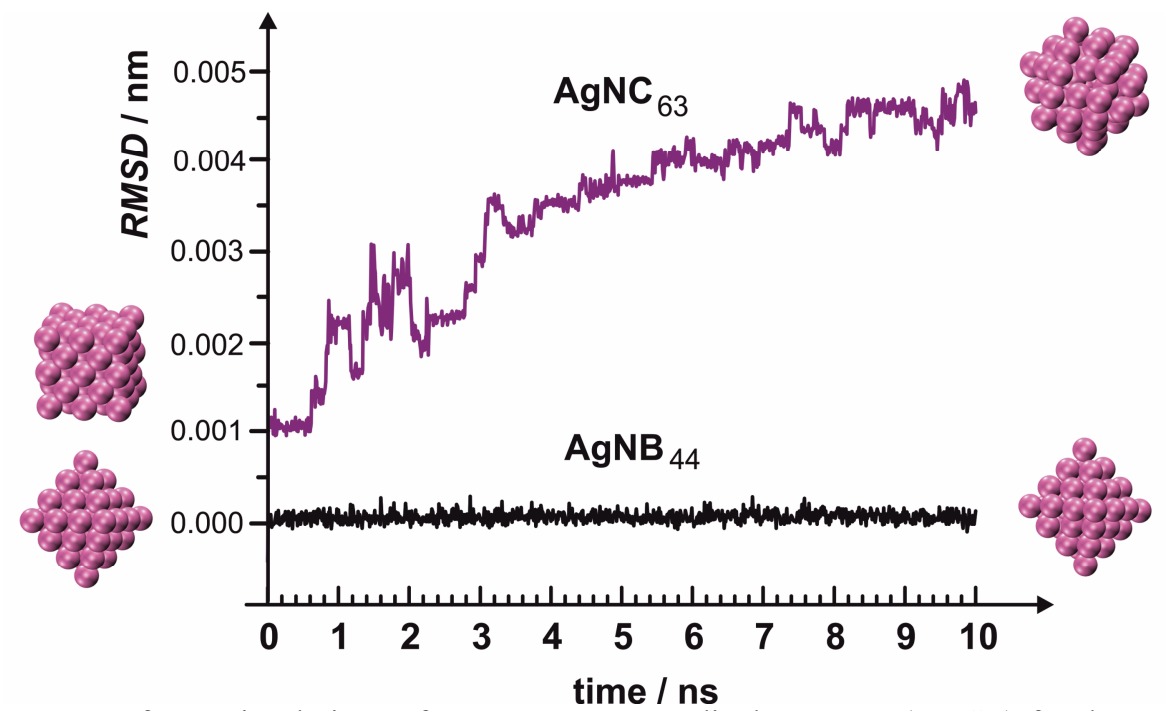

Figure 2. Time-traces of MD simulations of root mean square displacements $(R M S D)$ for the position of silver atoms in $\mathrm{AgNC}_{63}$ and $\mathrm{AgNB}_{44}$. Each $R M S D$ plot is normalized by the number of silver atoms in the system.

For comparison of the morphological stability of $\mathrm{AgNB}_{44}$ and $\mathrm{AgNC}_{63}$, their structures were analyzed by calculating the root mean square displacements $(R M S D)$ of $\mathrm{Ag}$ atoms as a function of time. The $R M S D$ of all $\mathrm{Ag}$ atoms was calculated with respect to their position in a perfect $f c c$ structure by least-square fitting of the nanoparticle structure $\left(\tau_{2}\right)$ to its initial perfect structure $\left(\tau_{1}=0\right)$ (Fig. 2$)$. MD simulations demonstrated that the smallest $\mathrm{AgNB}_{44}$ was capable to keep its initially preformed bipyramidal shape during $10 \mathrm{~ns}$ sampling period. In contrast, the complete loss of the cubic shape was evident for $\mathrm{AgNC}_{63}$ already after 2-3 ns (Fig. 2). 
Coordination Numbers of Ag atoms. In a $f c c$ unit cell the lattice atoms were located at each of the corners and the centers of all the cubic faces; therefore, each bulk Ag atom occupied the closedfacets site with the coordination number $(C N)$ of 12 . The coordination number decreased up to $9,7,4$ and 3 for the Ag atom that located at the side, edge, and corner of the cubic and bipyramidal shaped nanoparticles [34] (Fig. 3).

The analysis of the morphological stability of the studied systems showed that the loss of the perfect structure in the sharp-edged $\mathrm{Ag}$ nanoparticles was driven by the tendency of the outermost lowcoordinated $\mathrm{Ag}$ atoms located at the corners and edges to increase in their coordination number $(C N)$ by acquiring more neighboring surrounding atoms $[34,35]$. Upon going from $\mathrm{AgNCs}$ to AgNBs the $C N s$ of the corner atoms were increased from 3 up to 4 (Fig. 3). Therefore, AgNBs were characterized by the more stable morphology as compared with AgNCs of the same sizes. These findings explain the high morphological stability of quasi-spherical nanoparticles, in which corner and edge atoms are characterized by $C N=7$ (Fig. 3).

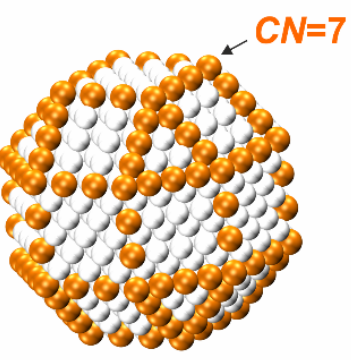

$\mathrm{AgNP}_{1048}$

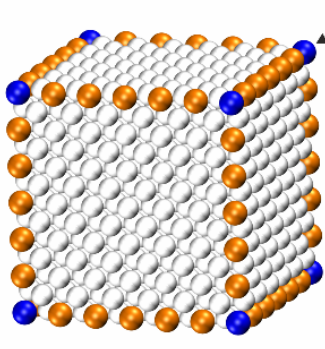

AgNC $_{1099}$

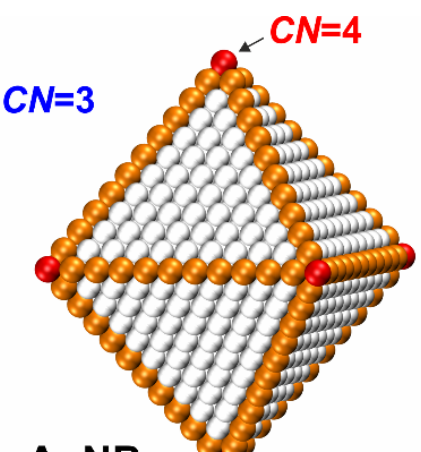

$\mathrm{AgNB}_{1156}$

Figure 3. Coordination number distribution of surface atoms in silver nanoparticles of different shape: In $\mathrm{AgNP}_{1048}, \mathrm{AgNC}_{1099}$ and $\mathrm{AgNB}_{1156}, \mathrm{Ag}$ atoms are color-coded according to their coordination number: corner atoms in $\mathrm{AgNC}$ (blue) $-C N=3$, corner atoms in $\mathrm{AgNB}($ red $)-C N=4$, edge atoms (orange) $-C N=7$, side atoms (white) $-C N \geq 9$. (For interpretation of the references to color in this figure legend, the reader is referred to the web version of this article.)

Binding Energy of Outermost Ag atoms. The Van der Waals binding energy of the certain atoms located at the corners and edges of the studied silver nanoparticles were considered by estimating their average LJ interaction energy calculated with the rest of the Ag atoms within the interaction cutoff distance $0.8 \mathrm{~nm}$. As mentioned above, for AgNCs composed of $N>256$, the perfect cubic shape was reproduced. However, some single Ag-atom lattice defects could still be observed. Fig. 4 shows the example of the formation of such single-atom defect and the time trace of the binding energy of a single corner $\mathrm{Ag}$ atom in $\mathrm{AgNC}_{500}$ calculated from the $\mathrm{MD}$ trajectory. The binding energy of the single corner Ag atom demonstrated the high-amplitude fluctuations around the initial plateau at $-76 \mathrm{~kJ} / \mathrm{mol}$ during the first $0.8 \mathrm{~ns}$. After that, the rapid hopping of the Ag atom toward the side position occurred leading to the binding energy decreased up to $-104 \mathrm{~kJ} / \mathrm{mol}$. The corner-to-side hopping of the selected $\mathrm{Ag}$ atom required the activation energy $\Delta \mathrm{E}_{\mathrm{a}}$ of $\sim 12 \mathrm{~kJ} / \mathrm{mol}$ (Fig. 4 ). $\Delta \mathrm{E}_{\mathrm{a}}$ was calculated as the difference between the average binding energy of the selected $\mathrm{Ag}$ atom (energy trajectory from 0 to $0.8 \mathrm{~ns}$ ) and the highest energy value observed before the hopping (dotted lines in Fig. 4). In $\mathrm{AgNB}_{670}$, no such corner atom hopping occurred, so that its binding energy was fluctuated around $-90 \mathrm{~kJ} / \mathrm{mol}$. In agreement with the increase in the coordination number (Fig. 3), the much larger binding energies of -149 and $-174 \mathrm{~kJ} / \mathrm{mol}$ were observed for the corner and edge atoms in $\mathrm{AgNP}_{1007}$ (Fig. 4). This fact explains the high structural stability of quasi-spherical silver nanostructures.

Thus, we suggest that the loss of the perfect cubic-shape, accompanied by rounding of the sharp edges and corners, is driven by the tendency of the outermost $\mathrm{Ag}$ atoms to acquire more neighboring surrounding atoms. The migration of the certain $\mathrm{Ag}$ atom from an edge or a corner should lead to the increase in their coordination number, so that their binding stabilization energy should also increase. It is also well recognized that physical and chemical properties of metal nanoparticles are strongly sizedependent because of their large surface-to-volume ratio [34, 36, 37]. In the studied AgNCs, the fraction of the outermost surface atoms $\left(\mathrm{F}_{\text {surf }}\right)$ was increased from $39.5 \%$ up to $85.7 \%$ when going from 
$\mathrm{AgNC}_{1099}$ to $\mathrm{AgNC}_{63}$, respectively. In $\mathrm{AgNC}_{63}$, the majority of the $\mathrm{Ag}$ atoms (54) were the weakest bound surface atoms. Therefore, these arguments explain the low stability of the cubic-shape morphology of small AgNCs and their rapid rearrangement to the nearly spherical shape that is more thermodynamically stable.

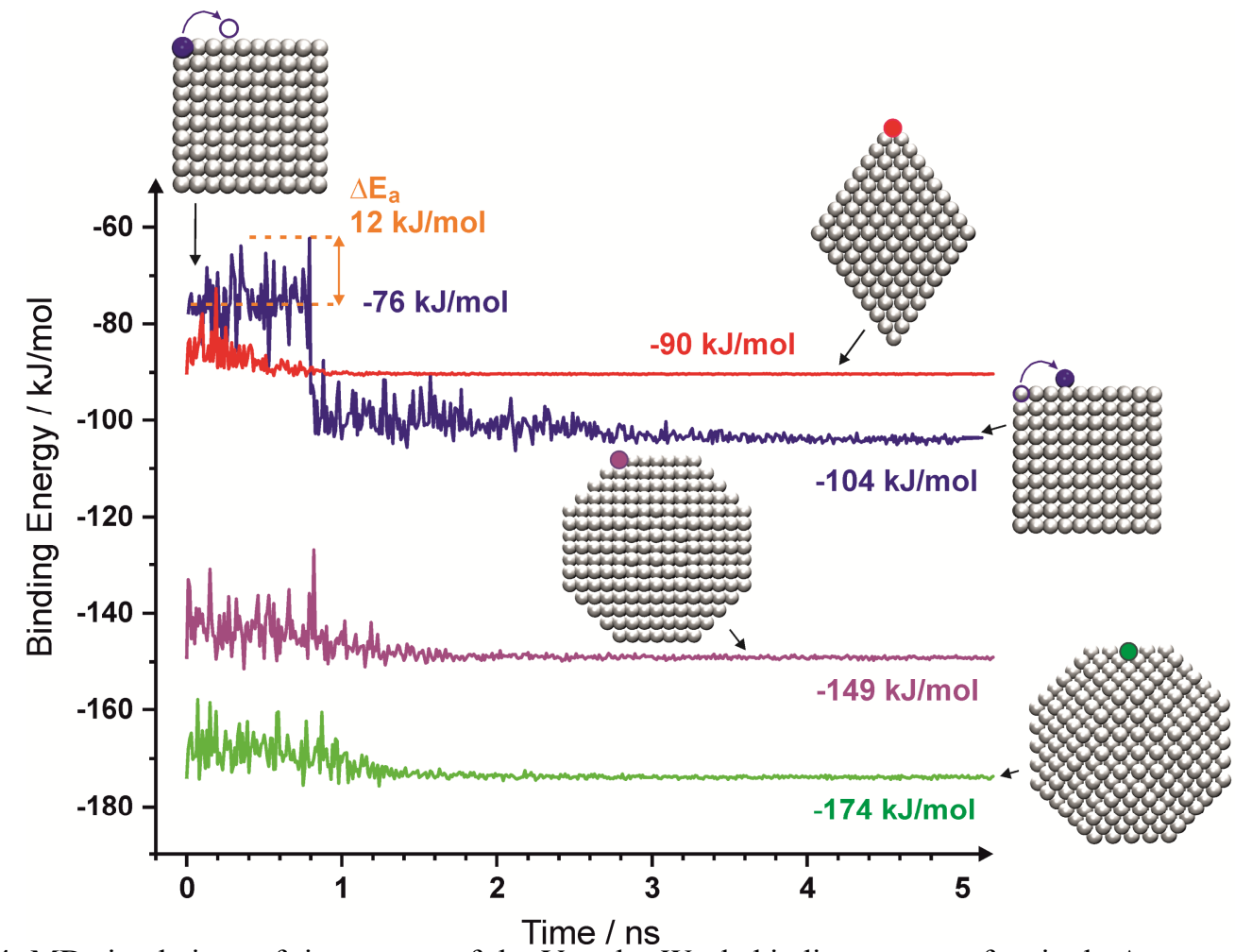

Figure 4. MD simulations of time traces of the Van der Waals binding energy of a single Ag atom located in different positions (color-coded) in the silver nanoparticles of the different shape.

\section{Summary}

Our MD simulations revealed that, starting from the preformed perfect crystalline structures, the morphological stability of a series of AgNCs and AgNBs depended on their shapes and sizes varying from 44 up to 1156 atoms. The rapid loss of the cubic-shape morphology and transformation into the non- $f c c$-structure were found for the smaller AgNCs composed of less than 172 atoms, which were not observed for bipyramidal and quasi-spherical nanoparticles of the same sizes. The analysis of the binding energy of the outermost Ag surface atoms suggests that the loss of the perfect cubic shape, rounding and smoothing of sharp edges and corners are driven by the tendency towards the increase in their coordination number. Therefore, the structure of AgNBs, in which its low-coordinated corner atoms have $C N=4$, is characterized by the more stable morphology as compared to AgNCs, in which its corner atoms have the smallest $C N=3$. Taken together, these results provide the new important physical insights onto the relative stabilities of various sharp-edged silver nanoparticles in the gas phase, which have further promising perspective in solution phase synthesis of polymer-protected silver nanoparticles.

\section{Acknowledgements}

The authors acknowledge Grant 0116 U000834 of the Ministry of Education and Science of Ukraine.

\section{References}

1. Eckhardt S., Brunetto P. S., Gagnon J., Priebe M., Giese B. and Fromm K. M. Nanobio silver: Its interactions with peptides and bacteria, and its uses in medicine. Chem. Rev. 2013. Vol. 113, № 7. P. 4708-4754. 
2. Rycenga M., Cobley C. M., Zeng J., Li W., Moran C. H., Zhang Q., Qin D. and Xia Y. Controlling the synthesis and assembly of silver nanostructures for plasmonic applications. Chem. Rev. 2011. Vol. 111, № 6. P. 3669-3712.

3. Stamplecoskie K., Silver nanoparticles: From bulk material to colloidal nanoparticles, in Silver Nanoparticle Applications: The Fabrication and Design of Medical and Biosensing Devices, Eds. E.I. Alarcon, M. Griffith, and K.I. Udekwu, 2015, Springer International Publishing: Cham. P. 1-12.

4. Helmlinger J., Prymak O., Loza K., Gocyla M., Heggen M. and Epple M. On the crystallography of silver nanoparticles with different shapes. Cryst. Growth Des. 2016. Vol. 16, № 7. P. 3677-3687.

5. Albanese A., Tang P. S. and Chan W. C. W. The effect of nanoparticle size, shape, and surface chemistry on biological systems. Ann. Rev. Biomed. Engeneer. 2012. Vol. 14, № 1. P. 1-16.

6. Xia Y., Xiong Y., Lim B. and Skrabalak S. E. Shape-controlled synthesis of metal nanocrystals: Simple chemistry meets complex physics? Angew. Chem., Int. Ed. 2009. Vol. 48, № 1. P. 60-103.

7. Xia Y., Gilroy K. D., Peng H.-C. and Xia X. Seed-mediated growth of colloidal metal nanocrystals. Angew. Chem. Int. Ed. 2017. Vol. 56, № 1. P. 60-95.

8. Kovalenko M. V., Manna L., Cabot A., Hens Z., Talapin D. V., Kagan C. R., Klimov V. I., Rogach A. L., Reiss P., Milliron D. J., Guyot-Sionnnest P., Konstantatos G., Parak W. J., Hyeon T., Korgel B. A., Murray C. B., and Heiss W. Prospects of nanoscience with nanocrystals. ACS Nano 2015. Vol. 9, № 2. P. 1012-1057.

9. Lucky S. S., Soo K. C. and Zhang Y. Nanoparticles in photodynamic therapy. Chem. Rev. 2015. Vol. 115, № 4. P. 1990-2042.

10. Matteini P., Cottat M., Tavanti F., Panfilova E., Scuderi M., Nicotra G., Menziani M. C., Khlebtsov N., de Angelis M. and Pini R. Site-selective surface-enhanced Raman detection of proteins. ACS Nano 2017. Vol. 11, № 1. P. 918-926.

11. da Silva A. G. M., Rodrigues T. S., Wang J., Yamada L. K., Alves T. V., Ornellas F. R., Ando R. A. and Camargo P. H. C. The fault in their shapes: Investigating the surfaceplasmon-resonance-mediated catalytic activities of silver quasi-spheres, cubes, triangular prisms, and wires. Langmuir 2015. Vol. 31, № 37. P. 10272-10278.

12. Tomalia D. A. and Khanna S. N. A systematic framework and nanoperiodic concept for unifying nanoscience: Hard/soft nanoelements, superatoms, meta-atoms, new emerging properties, periodic property patterns, and predictive Mendeleev-like nanoperiodic tables. Chem. Rev. 2016. Vol. 116, № 4. P. 2705-2774.

13. Jiang K. and Pinchuk A. O., Noble metal nanomaterials: Synthetic routes, fundamental properties, and promising applications, Solid State Physics, E.C. Robert and L.S. Robert, Editors. 2015, Academic Press. P. 131-211.

14. Tian P. Molecular dynamics simulations of nanoparticles. Ann Rep Sect C: Phys. Chem. 2008. Vol. 104, P. 142-164.

15. Konuk M. and Durukanoglu S. Shape-controlled growth of metal nanoparticles: An atomistic view. Phys. Chem. Chem. Phys. 2016. Vol. 18, № 3. P. 1876-1885.

16. Fichthorn K. A., Balankura T. and Qi X. Multi-scale theory and simulation of shape-selective nanocrystal growth. CrystEngComm 2016. Vol. 18, № 29. P. 5410-5417.

17. Fichthorn K. A. Atomic-scale theory and simulations for colloidal metal nanocrystal growth. J. Chem. Eng. Data 2014. Vol. 59, № 10. P. 3113-3119.

18. Martin L., Bilek M. M., Weiss A. S. and Kuyucak S. Force fields for simulating the interaction of surfaces with biological molecules. Interface Focus 2016. Vol. 6, № 1. P. 20150045.

19. Kyrychenko A., Karpushina G. V., Bogatyrenko S. I., Kryshtal A. P. and Doroshenko A. O. Preparation, structure, and a coarse-grained molecular dynamics model for dodecanethiolstabilized gold nanoparticles. Comput. Theor. Chem. 2011. Vol. 977, № 1-3. P. 34-39.

20. Kyrychenko A., Karpushina G. V., Svechkarev D., Kolodezny D., Bogatyrenko S. I., Kryshtal A. P. and Doroshenko A. O. Fluorescence probing of thiol-functionalized gold nanoparticles: Is alkylthiol coating of a nanoparticle as hydrophobic as expected? J. Phys. Chem. C 2012. Vol. 116, № 39. P. 21059-21068.

21. Henz B. J., Chung P. W., Andzelm J. W., Chantawansri T. L., Lenhart J. L. and Beyer F. L. Determination of binding energy and solubility parameters for functionalized gold nanoparti- 
cles by molecular dynamics simulation. Langmuir 2011. Vol. 27, № 12. P. 7836-7842.

22. Kyrychenko A., Korsun O. M., Gubin I. I., Kovalenko S. M. and Kalugin O. N. Atomistic simulations of coating of silver nanoparticles with poly(vinylpyrrolidone) oligomers: Effect of oligomer chain length. J. Phys. Chem. C 2015. Vol. 119, № 14. P. 7888-7899.

23. Milano G., Santangelo G., Ragone F., Cavallo L. and Di Matteo A. Gold nanoparticle/polymer interfaces: All atom structures from molecular dynamics simulations. J. Phys. Chem. C 2011. Vol. 115, № 31. P. 15154-15163.

24. Shen Z., Nieh M.-P. and Li Y. Decorating nanoparticle surface for targeted drug delivery: Opportunities and challenges. Polymers 2016. Vol. 8, № 3. P. 83.

25. Hwang J., Shim Y., Yoon S.-M., Lee S. H. and Park S.-H. Influence of polyvinylpyrrolidone (PVP) capping layer on silver nanowire networks: Theoretical and experimental studies. RSC Adv. 2016. Vol. 6, № 37. P. 30972-30977.

26. Balankura T., Qi X., Zhou Y. and Fichthorn K. A. Predicting kinetic nanocrystal shapes through multi-scale theory and simulation: Polyvinylpyrrolidone-mediated growth of $\mathrm{Ag}$ nanocrystals. J. Chem. Phys. 2016. Vol. 145, № 14. P. 144106.

27. Gracia-Pinilla M. Á., Pérez-Tijerina E., García J. A., Fernández-Navarro C., Tlahuice-Flores A., Mejía-Rosales S., Montejano-Carrizales J. M. and José-Yacamán M. On the structure and properties of silver nanoparticles. J. Phys. Chem. C 2008. Vol. 112, № 35. P. 13492-13498.

28. Mariscal M. M., Velazquez-Salazar J. J. and Yacaman M. J. Growth mechanism of nanoparticles: Theoretical calculations and experimental results. CrystEngComm 2012. Vol. 14, № 2. P. 544-549.

29. Kyrychenko A., Pasko D. A. and Kalugin O. N. Poly(vinyl alcohol) as a water protecting agent for silver nanoparticles: The role of polymer size and structure. Phys. Chem. Chem. Phys. 2017. Vol. 19, № 13. P. 8742-8756.

30. Berendsen H. J. C., Postma J. P. M., van Gunsteren W. F., DiNola A. and Haak J. R. Molecular dynamics with coupling to an external bath. J. Chem. Phys. 1984. Vol. 81, № 8. P. 3684-3690.

31. Van Der Spoel D., Lindahl E., Hess B., Groenhof G., Mark A. E. and Berendsen H. J. C. GROMACS: Fast, flexible, and free. J. Comput. Chem. 2005. Vol. 26, № 16. P. 1701-1718.

32. Humphrey W., Dalke A. and Schulten K. VMD: Visual molecular dynamics. J. Mol. Graphics 1996. Vol. 14, № 1. P. 33-38.

33. Gromacs user manual version 4.5.4 / Van Der Spoel D., Lindahl E., Hess B., van Buuren A. R., Apol E., Meulenhoff P. J., Tieleman D. P., Sijbers A. L. T. M., Feenstra K. A., van Drunen R., and Berendsen H. J. C. www.gromacs.org, 2010. P. 372.

34. Akbarzadeh H., Abbaspour M. and Mehrjouei E. Competition between stability of icosahedral and cuboctahedral morphologies in bimetallic nanoalloys. Phys. Chem. Chem. Phys. 2017. Vol. 19, № 22. P. 14659-14670.

35. Myshlyavtsev A. V., Stishenko P. V. and Svalova A. I. A systematic computational study of the structure crossover and coordination number distribution of metallic nanoparticles. Phys. Chem. Chem. Phys. 2017. Vol. 19, № 27. P. 17895-17903.

36. Ali S., Myasnichenko V. S. and Neyts E. C. Size-dependent strain and surface energies of gold nanoclusters. Phys. Chem. Chem. Phys. 2016. Vol. 18, № 2. P. 792-800.

37. Li Z. Y., Young N. P., Di Vece M., Palomba S., Palmer R. E., Bleloch A. L., Curley B. C., Johnston R. L., Jiang J. and Yuan J. Three-dimensional atomic-scale structure of size-selected gold nanoclusters. Nature 2008. Vol. 451, № 7174. P. 46-48.

Поступила до редакиії 5 жовтня 2017 р.

М.М. Блажинская, А.В. Кириченко, О.Н. Калугин. Молекулярно-динамическое моделирование наночастиц серебра кубической и бипирамидальной фрормы.

В данной статье рассмотрены кристаллические структуры остроугольных наночастиц серебра с совершенной гранецентрированной кубической (ГЦК) упаковкой атомов и их способность к макроскопической морфологической стабильности. Остроугольные наночастицы серебра представлены в форме кубов и бипирамид, и сравниваются с квази-сферическими наночастицами той же природы, с помощью метода 
классического молекулярно-динамического (МД) моделирования. Была исследована серия разноразмерных нанокубов (AgNC) и нанобипирамид (AgNB) серебра, которые содержат от 44 до 1156 атомов. Проведенное МД моделирование свидетельствует о том, что исходные совершенные кристаллические структуры, которые состоят из больше чем 256 атомов, сохраняют свою первичную фоорму. Исключительным является тот факт, что для AgNC, которые состоят из менее чем 172 атомов, была зафиксирована мгновенная потеря кубической формы и полное превращение в аморфную структуру. Однако, для нанобипирамид и квази-сферических наночастиц такой морфологической потери не происходило. Анализ энергии связи наиболее отдаленных атомов серебра от центра указывает на то, что превращение совершенной кубической формы в округлую и сглаженную происходит за счет изменения величины острого угла и координации атомов вершины, что связано со склонностью угловых атомов к увеличению своих координационных чисел.

Ключевые слова: серебро, наночастица, нанокуб, нанобипирамида, ГЦК, остроугольный, молекулярнодинамическое моделирование.

М.М. Блажинська, О.В. Кириченко, О.М. Калугін. Молекулярно-динамічне моделювання наночастинок срібла кубічної та біпірамідальної форми.

У даній статті розглянуті кристалічні структури гострокутних наночастинок срібла із досконалою гранецентрованою кубічною (ГЦК) упаковкою атомів та їх здатність до макроскопічної морфологічної стабільності. Гострокутні наночастинки срібла представлені у формі кубів та біпірамід, та порівнюються із квазісореричними наночастинками тієї ж природи, за допомогою методу класичного молекулярно-динамічного (МД) моделювання. Була досліджена серія різнорозмірних нанокубів (AgNC) та нанобіпірамід (AgNB) cpiбла, що містять від 44 до 1156 атомів. Проведене МД моделювання свідчить про те, що початкові досконалі кристалічні структури, які складаються із більш ніж 256 атомів, зберігають свою первинну форму. Винятковим $€$ той фракт, що для AgNC, які складаються із менш ніж 172 атомів, була зафіксована миттєва втрата кубічної форми і повне перетворення у аморфну структуру. Проте, для нанобіпірамід та квазісферичних наночастинок така морфологічна втрата не відбувалася. Аналіз енергії зв'язку найбільш віддалених атомів срібла від центру вказує на те, що перетворення досконалої кубічної фрорми в округлу та згладжену відбувається за рахунок зміни величини гострого кута та координації вершинних атомів, що пов'язано із схильністю кутових атомів до збільшення своїх координаційних чисел.

Ключові слова: срібло, наночастинка, нанокуб, нанобіпіраміда, ГЦК, гострокутний, молекулярнодинамічне моделювання.

Kharkov University Bulletin. Chemical Series. Issue 29 (52), 2017 